\title{
HUBUNGAN PENGETAHUAN DAN SIKAP TENTANG TUMBUH KEMBANG BALITA DI KLINIK BIDAN NOVI
}

\author{
Eka Sylviana Siregar \\ STIKes Sehat Medan, Medan, Indonesia \\ Email: ekasylvianasiregar@gmail.com
}

\begin{abstract}
Abstrak
Angka Kematian Bayi (AKB) menjadi indikator kesehatan pertama dalam menentukan derajat kesehatan anak. Data RISKESDAS 2018 untuk daerah Mandailing Natal dalam Proporsi pemantauan pertumbuhan dalam 12 bulan terakhir pada anak 0-59 bulan menurut Kabupaten/Kota di provinsi Sumatera Utara yaitu yang melakukan timbang berat badan sebanyak 231 orang $(47,96 \%)$ dengan frekuensi $<8$ kali $70,70 \%$, > 8kali 22,20\%, serta diukur panjang badan/tinggi badan dengan frekuensi 1 kali $14 \%$ dan $>2$ kali $76,32 \%$. Jenis Penelitian ini adalah deskriptif korelasional. Tehknik Pengambilan Sampel penelitian ini adalah total sampling sebanyak 35 orang. Hasil Penelitian, analisis uji Chi-Square diketahui bahwa nilai signifikan $\mathrm{p}$ value sebesar 0,027. Karena nilai $\mathrm{p}$ lebih kecil dari $0,05 \quad(0,027<0,05)$ maka Ha diterima sehingga pada penelitian ini terdapat hubungan yang signifikan antara pengetahuan dan sikap ibu dengan tumbuh kembang balita di Klinik Bidan Novi Tahun 2020. Hasil tersebut membuktikan bahwa ibu yang memiliki pengetahuan baik cenderung mempunyai sikap menerima dan positif terhadap tumbuh kembang balita. Diharapkan Bagi Tempat Penelitian, Institusi, Responden dan peneliti selanjutnya, agar memperhatikan tumbuh kembang balita, sehingga dapat mencapai hasil yang optimal.
\end{abstract}

Kata Kunci : Pengetahuan, Sikap, Tumbuh Kembang

\section{Abstract}

the Infant Mortality Rate (IMR) is the first health indicator in determining the health status of children. RISKESDAS 2018 data for the Mandailing Natal area in the Proportion of monitoring growth in the last 12 months in children 0-59 months by Regency/City in North Sumatra province, namely those who weigh 231 people (47.96\%) with a frequency of $<8$ times $70,70 \%$, > 8 times $22.20 \%$, and body length/height was measured with a frequency of 1 time $14 \%$ and $>2$ times $76.32 \%$. This type of research is descriptive correlational. The sampling technique of this research is a total sampling of 35 people. Research results, ChiSquare test analysis is known that the significant value of $p$ value is 0.027 . Because the $p$ value is smaller than $0.05(0.027<0.05)$ then $\mathrm{Ha}$ is accepted so that in this study there is a significant relationship between knowledge and attitudes of mothers with growth and development of toddlers at the Novi Midwife 
Clinic in 2020. These results prove that mothers who have Good knowledge tends to have an accepting and positive attitude towards toddler growth and development. It is hoped that research sites, institutions, respondents and further researchers will pay attention to the growth and development of toddlers, so that they can achieve optimal results.

Keywords: Knowledge, Attitude, Growth and Development.

\section{Pendahuluan}

Anak merupakan generasi penerus bangsa, sehingga kualitas gen er asi peneru s tergantung kualitas tumbuh kembang anak terutama pada bayi usia tiga tahun (balita), karna tiga tahun pertama kehidupan, pertumbuhan dan perkembangan sel-sel otak masih berlangsung, terjadi pertumbuhan serabutsyaraf dan cabang-cabangnya, sehingga terbentuk jarinfgan syaraf otak yang kompleks. Ju mlah pengaturan hubungan-hu bu ngan syaraf ini akan sangat mempengaruhi segala kinerja otak, mulai dari kemampuan belajar berjalan, mengenal huruf, hingga bersosialisasi (Ambarwati, 2014).

Menurut World Healt Organization (WHO), Angka Kematian Bayi (AKB) menjadi indikator kesehatan pertama dalam menentukan derajat kesehatan an ak karen a merupakan cerminan dari status kesehatan anak pada saat ini serta merupakan salah s atu indikator keberhasilan pembangunan suatu bangsa. Hal ini sesuai dengan program kesehatan yang dicanangkan dalam Millenium Development Goals (MDGs ) $2015 \mathrm{pad}$ a butir ke 4 dalam rangka menurunkan AKB 24 per 1000 kelahiran hidup (Kemenkes RI, 2015).

Jumlah balita yang mencapai $10 \%$ dari jumlah penduduk Indonesia yaitu 19.189.866, menjadikan tumbuh kembang balita sangat penting untuk diperhatikan karena menyangkut kualitas generasi masa depan bangsa. Berdasarkan hasil pelay anan Stimulasi Deteksi dan Intervensi Dini Tumbuh Kembang (SDIDTK)dari lima wilayah Jakarta pada 500 anak didapatkan 57 anak (11.9\%) mengalami kelainan tumbuh kembang. Kelainan tumbuh kembang yang paling banyak yaitu 22 anak mengalami delayed development (pertumbuhan yang terlambat), 14 anak mengalamiglobal delayed, 10 anak kurang gizi, 7 anak mengalami kelainan berat badan dalam beberapa bulan terakhir (Kemenkes RI, 2015).

Berdasarkan Data Riset Kesehatan Dasar (RISKESDAS) 2018 pemantauan pertumbuhan dan perkembangan balita sangat penting dilakukan untuk mengetahui adanya gangguan pertumbuhan (growth faltering) secara dini. Dari data Riskesdas tercatat ada 25 Kabupaten/kota didaerah Sumatera Utara yang memiliki prevalensi kependekan diatas angka prevalensi nasional $(3,27 \%)$. Urutan 5 tertinggi prevalensi kependekan yaitu, Langkat (55\%), Padang Lawas (54,9\%), Nias Utara $(54,7 \%)$ dan Pakpak Barat ( 52,3\%).

Dari data Dinas Kesehatan Mandailing Natal, terdapat anak gizi buruk dan mengakibatkan tumbuh kembang yang kurang dan terhambat pada tahun 2010 seban yak 
Vol. 1 Nomor 2

Tahun 2021

Hal. 54 - 60

25 orang, tahun 2011 sebanyak 20 orang, tahun 2012 sebanyak 26 orang dan pada tahu n 2017 sebanyak 14 orang (Dinkes Natal, 2017)

Berdasarkan survei yang dilakukan oleh peneliti di Klinik Bidan Novi, pen eliti mewawancarai 10 orang ibu yang mempunyai anak balita, sebanyak 7 orang ibu yang sudah mengetahui tentang tumbuh kembang balita dan 3 orang ibu kurang men ge tahui tentang tumbuh kembang balita.

\section{Metode Penelitian}

Jenis penelitian menggunakan deskriptifkorelasional guna mengetahui hubungan variabel bebas (independent) dan variabel terikat (dependent). Adapun sampel dalam penelitian ini, penulis menggunakan teknik total sampling yaitu teknik pengambilan sampel dimana jumlah sampel sama dengan populasi (Notoatmodjo, 2018). Jumlah sampel dalam penelitian ini adalah seluruh Ibu yang memiliki balita usia 3-5 tahun di Klinik Bidan Novi Tahun 2020 sebanyak 25 orang.

\section{Hasil dan Pembahasan}

Berdasarkan hasil penelitian di Klinik Bidan Novi Tahun 2020 diketahui data karakteristik res ponden berdasarkan umur, pendidikan, pekerjaan dan umur balita y ang diperoleh dari 25 responden. Hasil data karakteristik responden disajikan dalam bentuk tabel dibawah ini:

Tabel 4.1.

Data Karakteristik Responden di Klinik Bidan Novi Tahun 2020

\begin{tabular}{llcc}
\hline No & Data Demografi & Frekuensi & Presentase (\%) \\
\hline $\mathbf{1}$ & Umur & 5 & \\
& $<25$ tahun & 12 & 20,0 \\
& $25-35$ tahun & 8 & 48,0 \\
& $>35$ tahun & 25 & 32,0 \\
\hline \multicolumn{2}{c}{ Jumlah } & & 100 \\
\hline $\mathbf{2}$ & Pendidikan & \\
& SD & 0 & 0,0 \\
& SMP & 11 & 44,0 \\
& SMA & 5 & 36,0 \\
& Perguruan Tinggi & 5 & 20,0 \\
\hline$\quad$ Jumlah & 25 & 100 \\
\hline $\mathbf{3}$ & Pekerjaan & 15 & 60,0 \\
& IRT & 3 & 12,0 \\
& Pegawai Swasta & 5 & 20,0 \\
& Buruh & 2 & 8,0 \\
& PNS $\quad$ Jumlah & 100 \\
\hline & Umur Balita & \\
\hline $\mathbf{4}$ & $\quad$ & \\
\hline
\end{tabular}


Vol. 1 Nomor 2

Tahun 2021

Hal. 54 - 60

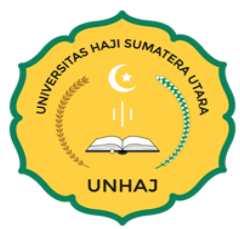

\begin{tabular}{cccc}
\hline No & Data Demografi & Frekuensi & Presentase (\%) \\
\hline & $3-4$ tahun & 14 & 56,0 \\
$4-5$ tahun & 11 & 44,0 \\
\hline & Jumlah & 25 & 100 \\
\hline
\end{tabular}

Dari tabel 4.1 karakteristik responden berdasarkan umur mayoritas berada pada rentang usia 25-35 tahun yaitu sebanyak 12 orang $(48,0 \%)$ dengan tin gk at pen didik an mayoritas SMP sebanyak 11 orang $(44,0 \%)$ dan berdasarkan pekerjaan mayoritas sebagai Ibu Rumah Tangga (IRT) sebanyak 15 orang $(60,0 \%)$. Rata-rata ibu memiliki balita u s ia 3-4 tahun yaitu sebanyak 14 orang $(56,0 \%)$.

Tabel 4.2

Distribusi Frekuensi Data Pengetahuan Ibu Dengan Tumbuh Kembang Balita di Klinik Bidan Novi Tahun 2020

\begin{tabular}{cccc}
\hline No & Pengetahuan Ibu & Frekuensi & Persentase $(\%)$ \\
\hline 1 & Baik & 5 & 20,0 \\
2 & Cukup & 9 & 36,0 \\
3 & Kurang & 11 & 44,0 \\
\hline & Jumlah & 25 & 100 \\
\hline
\end{tabular}

Berdas arkan tabel 4.2 di atas diketahui pengetahuan ibu tentang tumbuh kemban $g$ balita di Klinik Bidan Novi Tahun 2020 mayoritas memiliki pengetahuan kurang sebanyak 11 orang $(44,0 \%)$, sedangkan minoritas ibu memiliki pengetahuan baik sebanyak 5 orang $(20,0 \%)$.

Tabel 4.3

Distribusi Frekuensi Sikap Ibu Terhadap Tumbuh Kembang Balita di Klinik Bidan Novi Tahun 2020

\begin{tabular}{cccc}
\hline No & Sikap Ibu & Frekuensi & Persentase $(\%)$ \\
\hline 1 & Menerima & 16 & 64,0 \\
2 & Tidak Menerima & 9 & 36,0 \\
\hline & Jumlah & 25 & 100 \\
\hline
\end{tabular}

Berdasarkan tabel 4.3 di atas diketahui sikap ibu terhadap tumbuh kembang balita di Klinik Bidan Novi Tahun 2020 mayoritas memiliki sikap yang menerima (positif) sebanyak 16 orang $(64,0 \%)$, sedangkan ibu yang memiliki sikap tidak menerima (negatif) sebanyak 9 orang $(36,0 \%)$.

Tabel 4.4

Tabulasi Silang Hubungan Pengetahuan dan Sikap Ibu dengan Tumbuh Kembang Balita di Klinik Bidan Novi Tahun 2020

\begin{tabular}{|c|c|c|c|c|c|c|c|c|}
\hline \multirow{4}{*}{ No } & \multirow{4}{*}{ Pengetahuan } & \multirow{2}{*}{\multicolumn{4}{|c|}{$\begin{array}{l}\text { Sikap Ibu tentang Tumbuh } \\
\text { Kembang Balita }\end{array}$}} & \multirow{3}{*}{\multicolumn{2}{|c|}{ Total }} & \multirow{4}{*}{$p$-value } \\
\hline & & & & & & & & \\
\hline & & \multicolumn{2}{|c|}{ Menerima } & \multicolumn{2}{|c|}{ Tidak Menerima } & & & \\
\hline & & $f$ & $\%$ & $\bar{F}$ & $\%$ & $\mathrm{~F}$ & $\%$ & \\
\hline 1 & Baik & 5 & 20,0 & 0 & 0,0 & 5 & 20,0 & \multirow{2}{*}{0,027} \\
\hline 2 & Cukup & 7 & 28,0 & 2 & 8,0 & 9 & 36,0 & \\
\hline
\end{tabular}




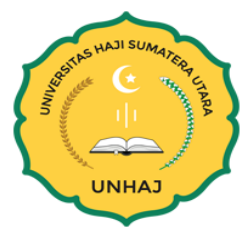

\begin{tabular}{|c|c|c|c|c|c|c|c|c|}
\hline \multirow{3}{*}{ No } & \multirow{3}{*}{ Pengetahuan } & \multicolumn{4}{|c|}{$\begin{array}{c}\text { Sikap Ibu tentang Tumbuh } \\
\text { Kembang Balita }\end{array}$} & \multirow{2}{*}{\multicolumn{2}{|c|}{ Total }} & \multirow[t]{3}{*}{$p$-value } \\
\hline & & \multicolumn{2}{|c|}{ Menerima } & \multicolumn{2}{|c|}{ Tidak Menerima } & & & \\
\hline & & $f$ & $\%$ & $\bar{F}$ & $\%$ & $\bar{F}$ & $\%$ & \\
\hline \multirow[t]{2}{*}{3} & Kurang & 4 & 16,0 & 7 & 28,0 & 11 & 44,0 & \\
\hline & Total & 16 & 640 & $\Omega$ & 360 & 25 & 1000 & \\
\hline
\end{tabular}

Berdasarkan analisa data pada tabel 4.4 di atas diketahui bahwa dari 5 responden yang berpengetahuan baik, keseluruhan memiliki sikap menerima sebanyak 5 orang $(20,0 \%)$ dan yang memiliki sikap tidak menerimatidak ada atau $0 \%$. Dari 9 res p onden yang berpengetahuan cukup, yang memiliki sikap menerima sebanyak 7 oran $g(28,0 \%)$ dan yang memiliki sikap tidak menerima sebanyak 2 orang $(8,0 \%)$. Sedan gk an d ari 11 responden yang berpengetahuan kurang, yang memiliki sikap menerima sebanyak 4 orang $(16,0 \%)$ dan yang memiliki sikap tidak menerima sebanyak 7 orang $(28,0 \%)$.

Hasil perhitungan analisis uji Chi-Square diketahui bahwa nilai signifikan $\mathrm{p}$ value sebesar 0,027. Karena nilai p lebih kecil dari 0,05 $(0,027<0,05)$ maka Ha diterima sehingga pada penelitian ini terdapat hubungan yang signifikan antara pengeta hu an $\mathrm{d}$ an sikap ibu dengan tumbuh kembang balita di Klinik Bidan Novi Tahun 2020. Hasil ters ebut membuktikan bahwa ibu yang memiliki pengetahuan baik cenderung mempunyai sikap menerima dan positif terhadap tumbuh kembang balita.

\section{Pengetahuan Ibu Dengan Tumbuh Kembang Balita di di Klinik Bidan Novi}

Berdasarkan hasil penelitian, didapatkan bahwa dari 25 responden yang telah diberikan kuisioner pengetahuan tentang tumbuh kembang balita sebagian besar responden dengan jumlah 11 responden $(44,0 \%)$ berpengetahuan kurang, 9 res pon den $(36,0 \%)$ berpengetahuan cukup dan 5 responden $(20,0 \%)$ berpengetahuan baik .

Hal tersebut sesuai dengan teori Notoatmodjo yang menyatakan bahwa pengetahuan seseorang akan baik apabila mendapat informasi yang baik juga sehingga informasi tersebut akan memberikan pengaruh pada tingkat pengetahuan seseorang (Notoatmodjo, 2016). Peneliti menyimpulkan bahwa tingkat pengetahuan tersebut dipengaruhi oleh salah satunya adalah tingkat pendidikan. Maka dari itu ibu yang tingk at pendidikannya tinggi akan memperkaya dirinya dengan ilmu-ilmu yang ber gu n a dalam deteksi tumbuh kembang anaknya baik dari internal maupun eksternal.

\section{Sikap Ibu Dengan Tumbuh Kembang Balita di Klinik Bidan Novi}

Berdasarkan hasil penelitian, didapatk an bahwa dari 25 responden yang telah diberikan kuisioner tentang pernyataan sikap ibu terhadap tumbuh kembang balita y aitu sebagian besar dari responden bersikap menerima (positif) terhadap tu m bu h kemban $\mathrm{g}$ balita dengan jumlah 16 responden $(64,0 \%)$, sedangk an responden bersikap tidak menerima terhadap tumbuh kembang balita sebanyak 9 responden $(36,0 \%)$. Sikap menerima ibu ditunjukkan oleh perny ataan setuju bahwa ibu membawa anak ke Posyandu setiap bulan, maka Ibu akan mengetahui tumbuh kembang anaknya, dan wa laupun sibuk bekerja tetapi Ibu tidak lupa untuk membawa anak Ibu untuk datang ke Posyandu s etiap bulannya.

Hasil tersebut sesuai dengan teori dari buku Sinta Fitriani (2011) yaitu sikap merupak an reaksi atau respon yang masih tertutup sebagian kecil dari responden menja wab setuju pada dari seseorang terhadap suatu stimulus atau objek. 


\section{Hubungan Pengetahuan dan Sikap Ibu dengan Tumbuh Kembang Balita di Klinik Bidan Novi}

Berdasarkan hasil tabulasi silang diketahui bahwa dari 5 responden yang berpengetahuan baik, keseluruhan memiliki sikap menerima sebanyak 5 orang $(20,0 \%)$ dan yang memiliki sikap tidak menerima tidak ada atau 0\%. Dari 9 responden yang berpengetahuan cukup, yang memiliki sikap menerima sebanyak 7 or an $g(28,0 \%)$ d an yang memiliki sikap tidak menerima sebanyak 2 orang $(8,0 \%)$. Sedangkan dari 11 responden yang berpengetahuan kurang, yang memiliki sikap menerima sebanyak 4 orang $(16,0 \%)$ dan yang memiliki sikap tidak menerima sebanyak 7 orang $(28,0 \%)$.

Hasil perhitungan analisis uji Chi-Square diketahui bahwa nilai signifikan $\mathrm{p}$ value sebesar 0,027. Karena nilai p lebih kecil dari 0,05 $(0,027<0,05)$ maka Ha diterima sehingga pada penelitian ini terdapat hubungan yang signifikan antara pengeta hu an $\mathrm{d}$ an sikap ibu dengan tumbuh kembang balita di Klinik Bidan Novi Tahun 2020. Hasil ters ebut membuktikan bahwa ibu yang memiliki pengetahuan baik cenderung mempunyai sikap menerima dan positif terhadap tumbuh kembang balita.

Hasil penelitian ini sejalan dengan penelitian yang dilakukan oleh Tariana Ginting tahun 2012 di Dusun VIII Desa Kolam Kecamatan Percut Sei Tuan Medan yaitu 36 responden yang berpengetahuan baik yang memiliki sikap positif sebany ak 5 orang $(13,89 \%)$ dan yang memiliki sikap negatif ada 2 orang $(5,56 \%)$, responden yang berpengetahuan cukup yang memiliki sikap positif sebanyak 8 orang $(22,22 \%)$ dan y ang memiliki sikap negatif sebanyak 7 orang $(19,44 \%)$ sedangkan yang berpengetahuan kurang yang memiliki sikap positif sebanyak 9 orang $(25 \%)$ dan yang memiliki sikap negatif sebanyak 5 orang $(13,89 \%)$. Setelah dilakukan uji Chi Square dengan SPSS dapat dilihat bahwa $\mathrm{p}=0,01<\mathrm{a}: 0,05$ maka Ho di tolak, Ha di terima artinya ad a hubungan yang bermakna artinya ada hubungan pengetahuan dengan sikap ibu dalam memantau perkembangan motorik pada balita usia 1 - 3 tahun.

Pengetahuan atau kognitif merupakan domain yang sangat penting dalam membentuk tindakan seseorang (over behavior) (Fitriani, 2011). Dalam teorinya Notoatmodjo menyatakan bahwa pengetahuan seseorang akan baik apabila mendapat informasi yang baik juga sehingga informasi tersebut akan memberikan pen gar uh pada tingkat pengetahuan seseorang (Notoatmodjo, 2010). Sikap itu merupakan kesiapan atau kesediaan untuk bertindak dan bukan merupakan pelaksanaan motif tertentu. Sikap merupakan kesiapan untuk bereaksi terhadap objek di lingkungan tertentu sebagai s u atu penghayatan terhadap objek (Maulana, 2010), serta sikap tidak di bawa sejak lahir, ak an tetapi dipelajari dan di bentuk berdasarkan pengalaman dan latihan sepanjang perkembangan seseorang agar tercipta sikap yang baik.

Dari hasil penelitian di atas menunjukkan bahwaibu yang berpengetah uan baik cenderung bersikap baik (mendukung), hal tersebut sesuai dengan teori Notoatmodjo menyatakan bahwa pengetahuan seseorang akan baik apabila mendapat inform a si y ang baik juga sehingga informasi tersebut akan memberikan pengaruh pada tingkat pengetahuan seseorang. Ketika seseorang mempunyai pengetahuan yang baik maka mereka akan cenderung mempunyai sikap yang positif dimana mereka akan melatih / melaksanakan sesuatu s esuai dengan pengetahuan yang dimilikinya karen a sikap y ang baik itu tidak dibawa sejak lahir, akan tetapi dipelajari dan dibentuk berdasarkan pengalaman dan latihan sepanjang perkembangan seseorang.

Hasil penelitian ini didapatkan hasil ada hubungan antara pengetahuan ibu dengan sikap terhadap tumbuh kembang balita di Klinik Bidan Novi tahun 2020, diman a dari data hasil penelitian menunjukan bahwaibu yang memiliki pengetahuan y ang baik cenderung memiliki sikap yang menerima yaitu 11 responden (100\%). Hal ini disebabkan oleh banyak faktor salah satunya adalah pendidikan. Pendidikan berpengaruh untuk 
membuat ibu yang memiliki anak balita memiliki informasi yang baik ten tan $\mathrm{g}$ tu $\mathrm{m}$ buh kembang serta mengakibatkan ibu memiliki sikap yang mendukung terhadap deteksi tumbuh kembang anaknya.

Jadi dapat disimpulkan bahwa dalam penelitian ini ada hubungan antara pengetahuan ibu dengan sikap terhadap tumbuh kembang balita di Klinik Bidan Novi tahun 2020, dimana dari data yang didapat ibu yang memiliki pengetahuan baik cenderung mempunyai sikap menerima dan positif.

\section{Kesimpulan}

Berdasarkan hasil penelitian maka dapat disimpulkan bahwa Ada hubungan yang signifikan antara pengetahuan dan sikap ibu dengan tumbuh kembang balita di Klinik Bidan Novi Tahun 2020, dengan nilai $p$ value $=0,027(\mathrm{p}<0,05)$. Hasil tersebut membuktikan bahwa ibu yang memiliki pengetahuan baik cenderung mempuny ai sikap menerima dan positif terhadap tumbuh kembang balitanya.

\section{Referensi}

A.Aziz Alimul, Hidayat. 2008. Pengantar Ilmu Kesehatan Anak untuk Pendidikan Kebidanan.Jakarta: Salemba Medika.

Ambarwati, E.R., Yahya, A.P., Sutanto, A.V. (2014). Tingkat Pengetahuan Ibu Tentang Stimulasi Tumbuh Kembang denganPerkembangan Pada Anak. Jurnal Kesehatan "Samodra Ilmu" Vol. 05 No. 02 Juli 2014. Yogyakarta. Akademi Kebidanan.

Dewi, R.C., Oktiawati, A., dan Saputri, L.D. 2016. Teori \& Konsep Tumbuh Kembang Bayi, Todller, Anak da Usia Remaja: Yogyakarta. Huha Medika.

Dudley L \& Vasche T., 2010. Vision Therapy For a Patient With Developmental Delay, Journal of Behavioral Optometry. Vol21. No.2.31 Mei 2011.

Dwienda, O., Maita L, S.M. Eka, Yulviana R. 2014. Asuhan Kebidanan Neonatus, Bayi/ Balita dan Anak Prasekolah Untuk Para Bidan: Yogyakarta

Husnah. 2015. Hubungan Pola Makan, Pertumbuhan dan Stimulasi dengan Perkembangan Anak Usia balita di Posyandu melati Kuta Alam banda Aceh: Jurnal Kedokteran Syiah Kuala Volume Nomor 2.

Imelda. 2017. Pengetahuan Ibu Tentang Pemberian Stimulasi dan Perkembangan Anak Pra Sekolah (3-5 Tahun) di Banda Aceh: Idea Nursing Jurnal. Vol VII No. 3

Indrayani, dkk. 2019. Pengaruh Kelas Ibu Balita Meningkatkan Pengetahuan dan Keterampilan Ibu dalam Stimulasi Tumbuh Kembang: Jurnal Kesehatan Prima.

Kemenkes RI (2014). Peraturan Menteri Kesehatan Republik Indonesia Nomor 66 Tahun 2014 tentang Pemantauan Pertumbuhan, Perkembangan dan Gangguan Tumbuh Kembang Anak. Jakarta: Kemenkes RI.

Notoathmodjo 2018. Metode Penelitian Kesehatan. Jakarta: Rineka Cipta

Notoatmodjo, Soekidjo.2012. Promosi Kesehatan Teori dan Aplikasi. Jakarta: Rineka Cipta

Palasari, Wina, dan Dewi Ika Sari H.P. 2012. Keterampilan Ibu dalam Deteksi Dini Tumbuh Kembang terhadap Tumbuh Kembang Bayi. Stikes RS Baptis Kediri: Jurnal Stikes. Volume 5, No. 1. Juli 2012.

Riskesdas, 2019.Laporan Provinsi Sumatera Utara Riskesdas 2018. Bad an Penelitian dan Pengembangan Kesehatan.

Saputra, Wahyu Indra dan Irdawati. 2018. Hubungan Tingkat Pengetahuan Ibu dengan Tumbuh Kembang Bayi Prematur Usia 6-12 Bulan di Wilayah Kerja Puskesmas Kecamatan banjarsari 